\title{
Natural Disasters, Geotourism, and Geo-interpretation
}

\author{
Piotr Migoń ${ }^{1}$ (D) Edyta Pijet-Migoń ${ }^{2}$ \\ Received: 27 June 2017 / Accepted: 4 July 2018 / Published online: 14 July 2018 \\ (C) The Author(s) 2018
}

\begin{abstract}
Natural disasters may be considered as opportunities to learn about the magnitude of natural processes and to better understand the role of human factors, especially exposure to risk. In this paper, we look at sites of past natural disasters from the perspective of geotourism. In a number of archeological sites from antiquity, one may see evidence of thorough destruction, mainly due to earthquakes and volcanic eruptions, although these sites are explored as glimpses into the past style of life rather than lessons about the power of nature. Twentieth and twenty-first century disasters are commemorated with monuments and plaques, but the tangible evidence of destruction is often quickly erased, both intentionally and due to post-event natural processes themselves. In this way, opportunities to use disaster sites as learning grounds are lost. However, there are examples of educational trails and museums, which illustrate the value of preserving some evidence of infrequent, but catastrophic events.
\end{abstract}

Keywords Dark tourism $\cdot$ Disasters $\cdot$ Earthquakes $\cdot$ Geomorphological change $\cdot$ Geotourism $\cdot$ Mass movements $\cdot$ Volcanic eruptions

\section{Introduction}

Most natural disasters, apart from disrupting everyday life and causing fatalities, leave tangible evidence of destruction. This evidence can be broadly divided into two categories: (a) changes in the natural environment resulting from catastrophic processes (Alcántara-Ayala and Goudie 2010) and (b) damaged infrastructure due to impact of these processes (Galderisi and Ceudech 2013; Saatcioglu 2013). The former involves landform change, alterations of hydrological conditions, soil change, and changes in vegetation patterns, whereas disasteraffected infrastructure includes buildings, transportation facilities (mainly roads and railways), transmission and supply lines, and protective constructions. Post-disaster recovery operations typically prioritize removal of this tangible evidence and rebuilding of damaged objects, which-from the perspective of affected communities - is both expected and

Piotr Migoń

piotr.migon@uwr.edu.pl

1 Institute of Geography and Regional Development, University of Wrocław, pl. Uniwersytecki 1, 50-137 Wrocław, Poland

2 Wrocław School of Banking, Institute of Tourism, Fabryczna 29-31, 53-609 Wrocław, Poland understandable. Whereas complete rebuilding may take years or even decades, obliteration of landform change usually proceeds at a faster rate, especially if the magnitude of a disaster was minor to moderate. Although subsequent natural processes themselves act towards erasing traces of natural disasters, human interventions speed this up and are undertaken particularly in places where landform change due to a disastrous event interferes with established land use patterns, property rights, and communication lines. All these circumstances lead to the situation in which material evidence of an event disappears, and this is followed by gradual disappearance of such an event from human memory, save those directly affected and their families. While this may help to overcome the disaster-induced trauma (Lindell 2013; Shultz et al. 2013), it also means that little may remain to alert us that disasters occur and that certain localities are more vulnerable than others.

Coratza and De Waele (2012) reviewed selected Italian examples of natural catastrophes and underlined the importance of such sites for geo-education, noting also inadequate facilities at most sites they presented. In this paper, we also argue that leaving some of the evidence of disasters may have positive effects for learning, understanding, and aiding recovery of affected sites and intend to further explore the relationships between hazards, disasters, geoheritage, and geotourism. Therefore, the paper is divided into several sections. First, we 
clarify general relationships between natural hazards, catastrophes, and tourism. Then, we review the type of tangible evidence produced by natural disasters of different types. Subsequently, we show how sites of disasters, which occurred in the distant past, have become obvious tourist attractions, followed by presentation of specific localities where partial evidence of a relatively recent disastrous event was intentionally or unintentionally preserved and now serves as an object of tourism interest (Fig. 1). In the closing part, we discuss the effectiveness of interpretation offered at such sites, point out missing opportunities to enhance the educational potential of the sites, and recommend good practice solutions.

\section{Natural Disasters and Tourism}

Among social phenomena associated with natural disasters, both ancient and more recent, are trips to the affected places driven by curiosity. Thus, these travels may be considered as a form of tourism (Stone et al. 2018). Interestingly, while sites of disasters from antiquity are considered as significant tourist attractions and promoted as such (e.g., Pompeii, Italy or Santorini, Greece), even if they were associated with huge loss of life, trips to localities affected by relatively recent events have rather bad connotations. This is because of socially less approved motivations to undertake the trip to a disaster site (Kelman and Dodds 2009, Rucińska and Lechowicz 2014). These dilemmas are particularly strong in the case of travels performed shortly after a calamity, when the evidence of devastation (itself a magnet for tourism) is still visible, but suffering is still severe and disaster trauma widely present (Tang 2018). People affected by disasters disapprove increasing curiosity-driven interest in the locality, manifested in taking photos and collecting "souvenirs" rather than offering help (Kelman and Dodds 2009). In addition, visiting sites of recent disasters may be still dangerous due to ongoing, albeit less intense volcanic activity (ErfurtCooper 2011), the likelihood of aftershocks, or instability of weakened river banks and dykes after floods (Rucińska 2016). For example, after the explosion of Mount St Helens on 18 May 1980, tourists flocked to the site to see an active volcano, often ignoring the risk. In consequence, there were 20 tourists among the total of $57 \mathrm{fa}-$ talities (Kelman and Dodds 2009).

Tourism to disaster sites falls within the scope of "dark tourism" (Stone et al. 2018). The phenomenon of dark tourism was first described and defined by

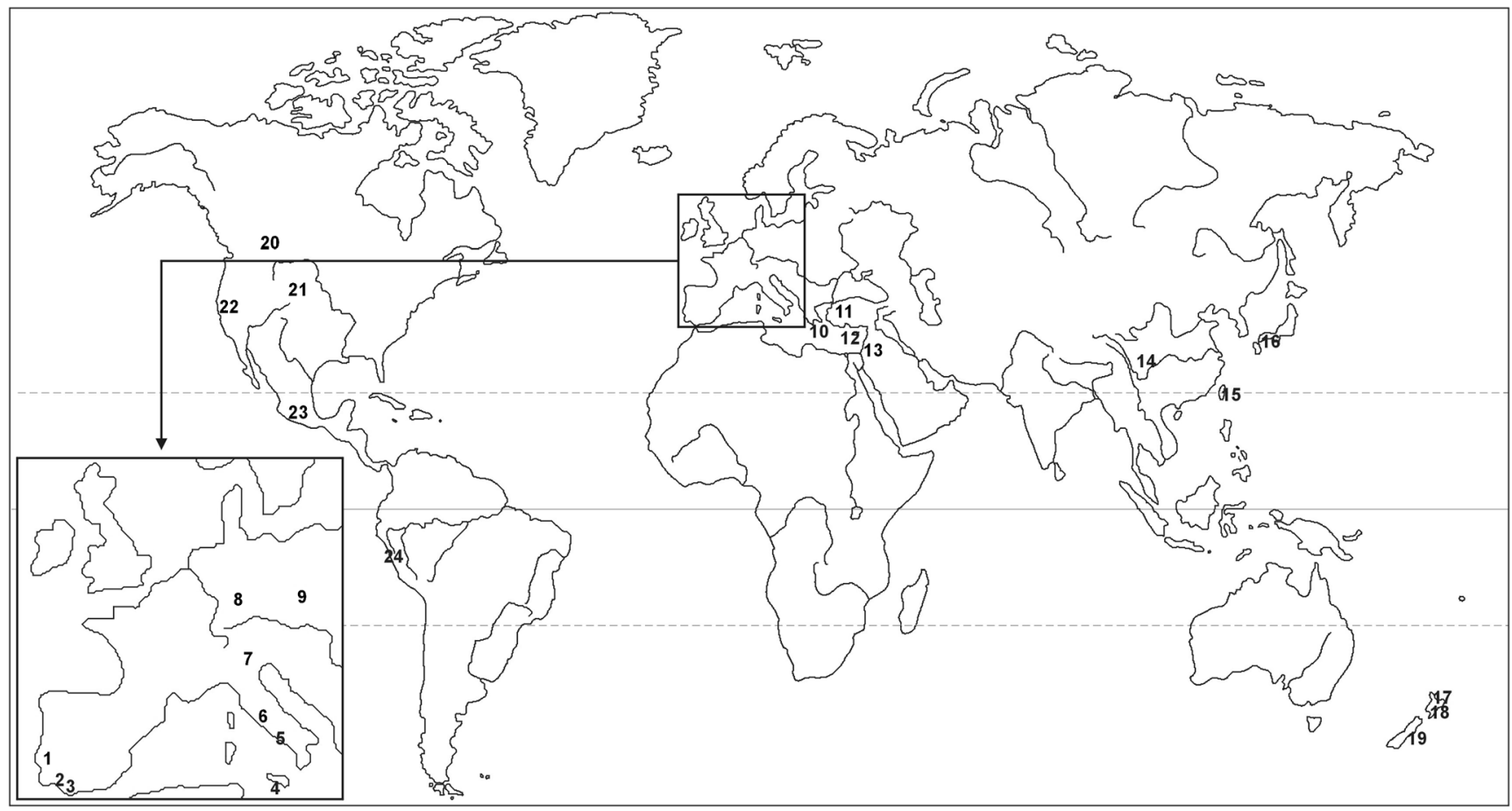

Fig. 1 Location map indicating localities referred to in the paper. $1-$ Lisbon (Portugal), 2-Cape Trafalgar (Spain), 3-Baelo Claudia (Spain), 4-Selinunte (Italy), 5-Pompeii and Herculaneum (Italy), 6Civita di Bagnoregio (Italy), 7-Vajont (Italy), 8-Eibelstadt (Italy), 9Obř́ důl, Karkonosze Mts. (Czechia), 10-Santorini (Greece), 11Hierapolis (Turkey), 12-Kourion (Cyprus), 13-Dead Sea Graben
(Israel, Jordan), 14-Wenchuan (China), 15-Wufeng (Taiwan), 16Kobe (Japan), 17-Te Wairoa (New Zealand), 18-Tangiwai (New Zealand), 19-Christchurch (New Zealand), 20-Frank (Canada), 21Rapid City (USA), 22 - Crescent City (USA), 23-Parícutin (Mexico), 24 -Yungay (Peru) 
Foley and Lennon (1996) as "Tourism involving travel to places historically associated with death and tragedy." Roughly at the same time another term came into being, "thanatourism," meaning travels to places associated with death, mainly mass deaths (extermination sites) (Seaton 1996; Tanaś 2013). Thus, there is some overlap between these two terms but dark tourism is wider in scope. Although dark tourism is a new notion, travels to disaster sites and localities affected by tragedies of various sorts can be traced back to the beginnings of modern tourism, to Grand Tour times of the seventeenth and eighteenth centuries (Timothy and Boyd 2003; Wallace 2012). Visits to archeological sites, learning about history and style of life, actually often interrupted by sudden events (not only natural), were important elements of early heritage tourism and continue to be so nowadays. Human tragedy and death are inseparable components of history and cannot be ignored (Korstanje and George 2015).

Depending on the causes of a disaster, one can distinguish between natural disaster tourism (Miller 2008; Rucińska 2016) and technological (anthropogenic) disaster tourism, the latter denoting travels to sites affected by industrial catastrophes, e.g., to Chernobyl in Ukraine. Geotourism, in turn, as part of nature-based tourism, is usually defined through the primary object of interest, which is geology and landforms as well as relevant natural processes, past, and present (Hose 1995, 2012; Newsome and Dowling 2005). However, the practice shows that the history of mining and harnessing natural resources in general is also included within geotourism, and so are disasters associated with exploitation history, especially if geomorphic evidence of such disasters survived and is available for viewing. Figure 2 shows the relationships between these different types of tourism.

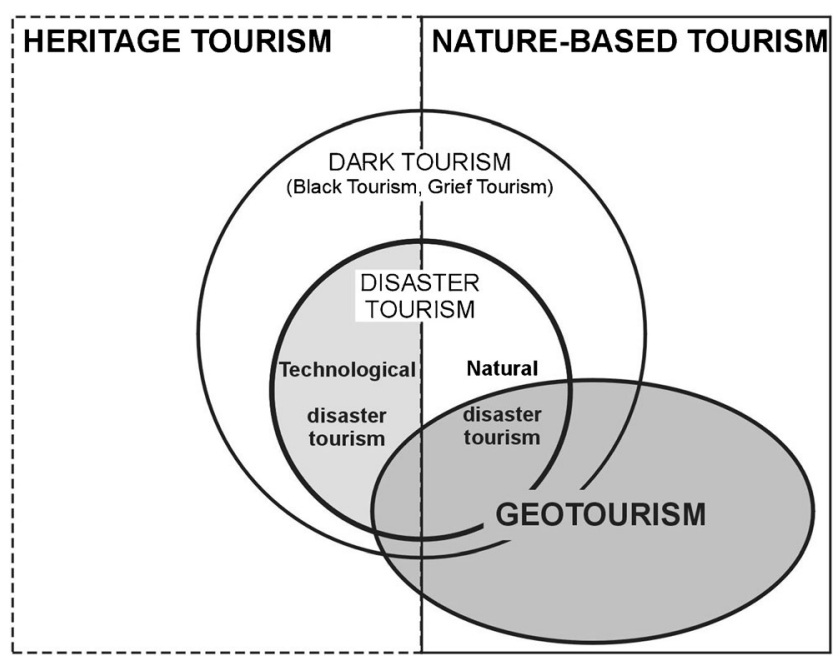

Fig. 2 Different types of tourism in relation to visitations to disaster sites

\section{Evidence of Natural Disasters that Can Survive}

Catastrophic natural events bring about two kinds of evidence that may persist (Table 1). First, new landforms are created and a certain thickness of cover deposits may form in particular places. Some of these landforms have huge dimensions, even measured in kilometer-scale and are evident for long after the actual event took place. This is the case of volcanic eruptions producing extensive lava flows. For example, the eruptive activity of Parícutin volcano in central Mexico in 1944 resulted in the origin of a large lava field and two lava flows up to 10-km long and 50-m thick, which spread far from the cone and buried two towns on their way, leaving only one church tower as a witness of the former settlement (AlcántaraAyala 2010). Gigantic dimensions may also be attained by mass movement caused by large landslides. The depositional body of the 1963 Vajont slide in Italy is approximately 4-km wide and 2-km long (Fig. 3a), enough to completely fill a reservoir that existed at the foot of the affected slope prior to the event (Semenza and Ghirotti 2000). Landslide scars can also be very persistent. Direct evidence of earthquakes, despite their severity, is more subtle and includes the origin of fault scarps, which may be long, but are hardly more than a few meters high, open ground fissures and closed waterlogged depressions along fault traces. Because of size, landforms of this kind are quickly degraded (Wallace 1977), especially in warm and humid climates, where abundant rainfall and dense vegetation contribute to landform degradation. However, earthquakes may also be accompanied by considerable landslide activity, and this evidence is much more persistent than seismotectonic landforms themselves. A supporting example derives from the area affected by the Wenchuan earthquake in Sichuan, China, in 2008, where more than 2000 landslides were triggered on slopes in the affected region (Chigira et al. 2010, Tang et al. 2011). More localized, but still of considerable size may be sinkholes in karstic terrains, whose collapse variant may appear suddenly and persist for long time after the event, unless anthropogenically filled (Waltham et al. 2005; Parise and Gunn 2007).

By contrast, evidence of water-related hazards, such as floods in inland and storms/tsunamis in coastal settings, is usually less evident, unless the magnitude of the event was very large. Whereas floods in steep mountainous terrains often occur as hyper-concentrated flows, capable of transporting large boulders, which are then left in channels and on valley floors as sedimentary evidence, lowland floods are typified by extensive inundations, whose sedimentary record may be surprisingly scarce. More striking are changes in channel position (avulsions), meander cutoffs, and transformations of channel patterns, but these are less common (Wohl 2000). Furthermore, flood-induced channel pattern change may be temporary and becomes naturally obliterated by subsequent, low to medium discharges. Likewise, tsunamis on boulder 
Table 1 Possible tangible evidence of natural disasters

\begin{tabular}{|c|c|c|}
\hline Type of disaster & New landforms/sediments & Impact on structures \\
\hline Volcanic eruption & $\begin{array}{l}\text { Lava flows and fields } \\
\text { Ash layers }\end{array}$ & $\begin{array}{l}\text { Burial } \\
\text { Fire }\end{array}$ \\
\hline Earthquake & $\begin{array}{l}\text { Fault scarps } \\
\text { Tilted surfaces } \\
\text { Sediment deformation }\end{array}$ & $\begin{array}{l}\text { Collapse } \\
\text { Structural damage } \\
\text { Displacement }\end{array}$ \\
\hline Tsunami/storm wave & $\begin{array}{l}\text { Fine-grained coastal deposits } \\
\text { Boulders } \\
\text { Barrier breaches }\end{array}$ & Structural damage \\
\hline Landslides, debris flows, and rockfalls & $\begin{array}{l}\text { Scars } \\
\text { Colluvium } \\
\text { Diverted drainage } \\
\text { Dammed lakes }\end{array}$ & $\begin{array}{l}\text { Buried/drowned structures } \\
\text { Abandoned settlements } \\
\text { Collapse } \\
\text { Structural damage }\end{array}$ \\
\hline Ground subsidence & Sinkholes & Collapse \\
\hline Floods & $\begin{array}{l}\text { Channel and overbank deposits } \\
\text { Avulsion channels } \\
\text { Downcutting } \\
\text { Boulders }\end{array}$ & $\begin{array}{l}\text { Burial } \\
\text { Collapse } \\
\text { Bridge destruction }\end{array}$ \\
\hline Soil erosion & $\begin{array}{l}\text { Gullies } \\
\text { Wash footslope deposits }\end{array}$ & Burial \\
\hline Sand storm & $\begin{array}{l}\text { Dune } \\
\text { Coversand }\end{array}$ & Burial \\
\hline
\end{tabular}

coasts will leave their traces in the form of specific boulder accumulations (Scheffers and Kelletat 2003), but if the sediment washed ashore was fine-grained, visible evidence of the event may disappear remarkably quickly (Szczuciński, 2012). All these disaster-produced landforms and deposits become potential carriers of information helping to better understand the magnitude of geological forces and geomorphic change.

Second, each type of disaster results in damaged infrastructure, although the nature of damage is not identical. Most high-energy events, such as earthquakes, debris flows, rock avalanches, major floods, storms, and tsunamis, are able to bring about complete destruction of buildings (collapse, removal). Smaller magnitude events result in structural damage, which may be such that strengthening and rebuilding is no longer feasible and partially affected structures are demolished anyway. This was the fate of most buildings in the center of Christchurch, New Zealand, which experienced a devastating earthquake in 2011. Certain types of landslides may displace buildings, transporting them as rafts on top of sliding masses. Perched, partly ruined buildings above landslide scars and broken communication facilities in analogous settings are further material evidence of landslides. Finally, constructions may suffer from partial or complete burial by displaced material and this may occur during volcanic eruptions (by lava or ash), due to debris flows, landslides, slope wash, and particularly intense sand storms.

\section{Ancient Natural Disaster Sites as Objects of Tourist Interest}

Many ancient and medieval communities were exposed to natural hazards and disasters, particularly related to seismic and volcanic activity, as well as to catastrophic fluvial and coastal geomorphic processes. There are numerous examples of once flourishing towns and trade centers which never recovered from a disaster and, while still existing, were gradually losing importance, whereas examples of complete destruction and disappearance or abandonment are also available. Locations of this kind are particularly common in the Mediterranean region of southern Europe and Middle East. First, highly advanced societies lived in the region since ancient times, capable of building monumental structures and developing urban style of life, thus producing legacy that could hold evidence of disasters. Second, the region is particularly prone to natural hazards, among which earthquakes, volcanic eruptions, tsunamis, landslides, and floods are most frequent. There are also examples from more recent times, and although complete abandonment was rare and re-building was the preferred option, certain disaster-affected places retained some evidence of the tragic event until nowadays. 
Fig. 3 Site of the 1963 Vajont Dam disaster (Italy). a General view of the landslide-affected slope. $\mathbf{b}$ Information panel next to the dam. c Observation deck in the village of Casso, without any interpretation facilities despite an excellent overview of the setting (all photos by P. Migoń)
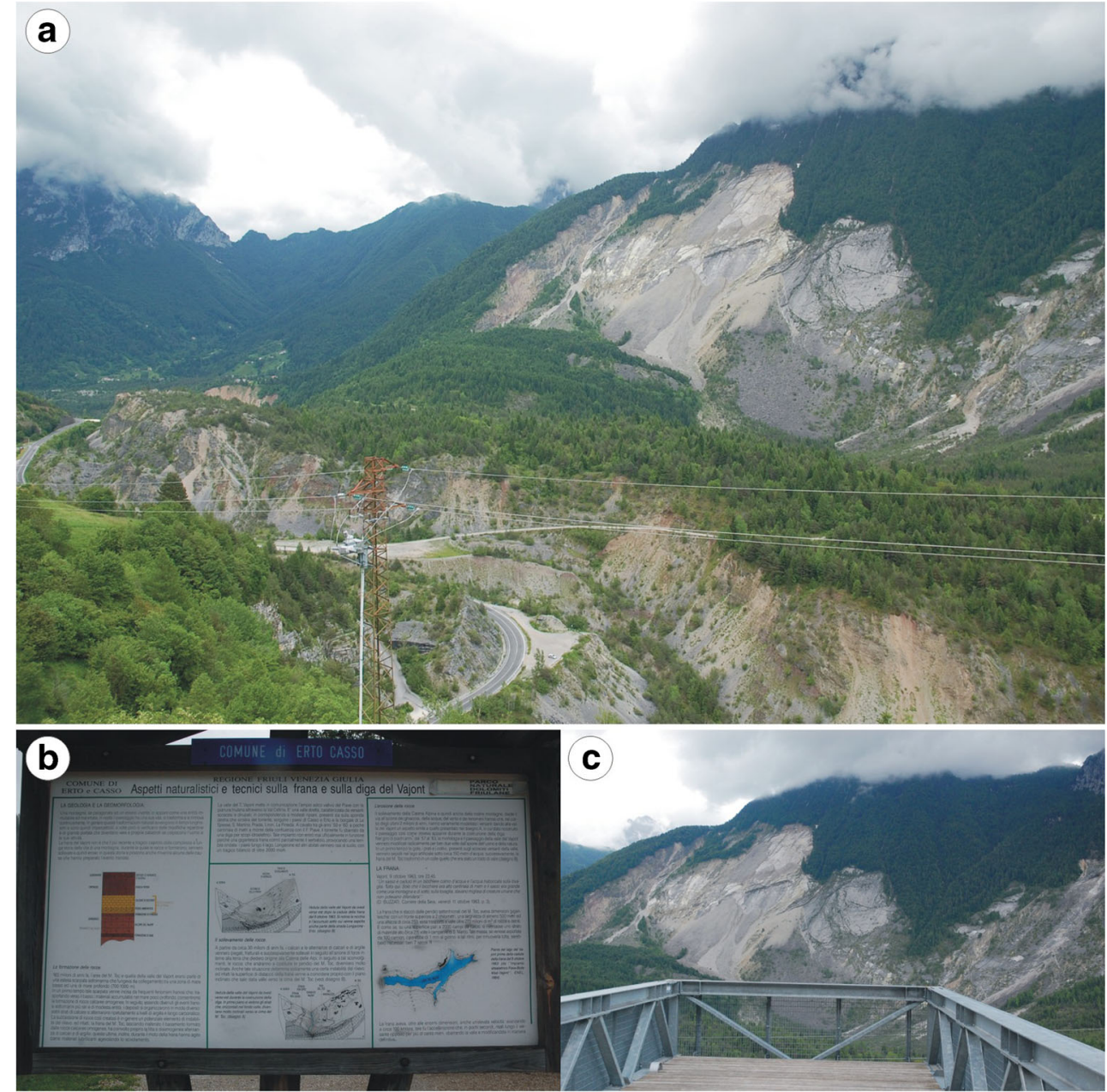

\section{Pompeii and Herculaneum}

Perhaps, the best known and most visited sites affected by a disaster nearly 2000 years ago are Pompeii and Herculaneum in Italy, at the footslopes of Mt. Vesuvius (Fig. 4). Both fell victims to a massive eruption in $79 \mathrm{AD}$ and were completely destroyed and buried under a layer of pyroclastic deposits and lahars (Sigurdsson et al. 1982; Lopes 2005). Pompeii was discovered for tourism more than 250 years ago and was an important point on the Grand Tour itinerary in the eighteenth and nineteenth centuries (Wallace 2012). Many well-known artists, authors, scholars, and aristocrats from all over Europe visited the archeological sites, including Johann Wolfgang Goethe, who visited Pompeii and climbed Mt. Vesuvius in March 1787 (Scandone and Giacomelli 2014). In 1997, the archeological area of Pompeii was included in the UNESCO World Heritage list. Now, it is visited by approximately three million people per year and more than 20,000 per day in high season. Excavations of ruins of the city continue, as well as restoration and strengthening of exposed buildings forcing temporary closures of some parts of the archeological site.
Nevertheless, tourists have a vast area to explore, hard to fully examine even in one full day. Herculaneum is a much smaller site at the western footslope of Mt. Vesuvius and is only partially excavated due to massive urban development, which has taken place in the area in the last 200 years. In contrast to Pompeii, where the thickness of volcanic deposits was a few meters, Herculaneum was buried by c. $20 \mathrm{~m}$ of sediment, causing the shift of the coastline by approximately $1 \mathrm{~km}$ due to the massive deposition. These layers of sediment can now be seen exposed overlooking the location of the ancient waterfront, where they provide spectacular, although little explained evidence of contemporary depositional processes (Fig. 4a). Visitor numbers at Herculaneum are significantly lower, reaching approximately 300,000 annually (as for 2015).

Despite an obvious relationship with the volcanic disaster and clear views towards the cone of Mt. Vesuvius from both destroyed cities (Fig. 4b), the subject of hazard and risk is surprisingly little explored at the sites themselves. In particular, insufficient connections are made between the fate of Pompeii and Herculaneum and the contemporary risk 
Fig. 4 Evidence of $79 \mathrm{AD}$ eruption of Mt. Vesuvius (Italy). a More than $15 \mathrm{~m}$ of lahar and pyroclastic deposits exposed in the archeological excavation at Herculaneum. The wooden boardwalk in the bottom of the trench is located at the preeruption sea level. b View towards Mt. Vesuvius across the ruins of Pompeii. Despite such an obvious causal link, the contemporary hazard and risk issues are poorly explored and explained (all photos by P. Migoń)
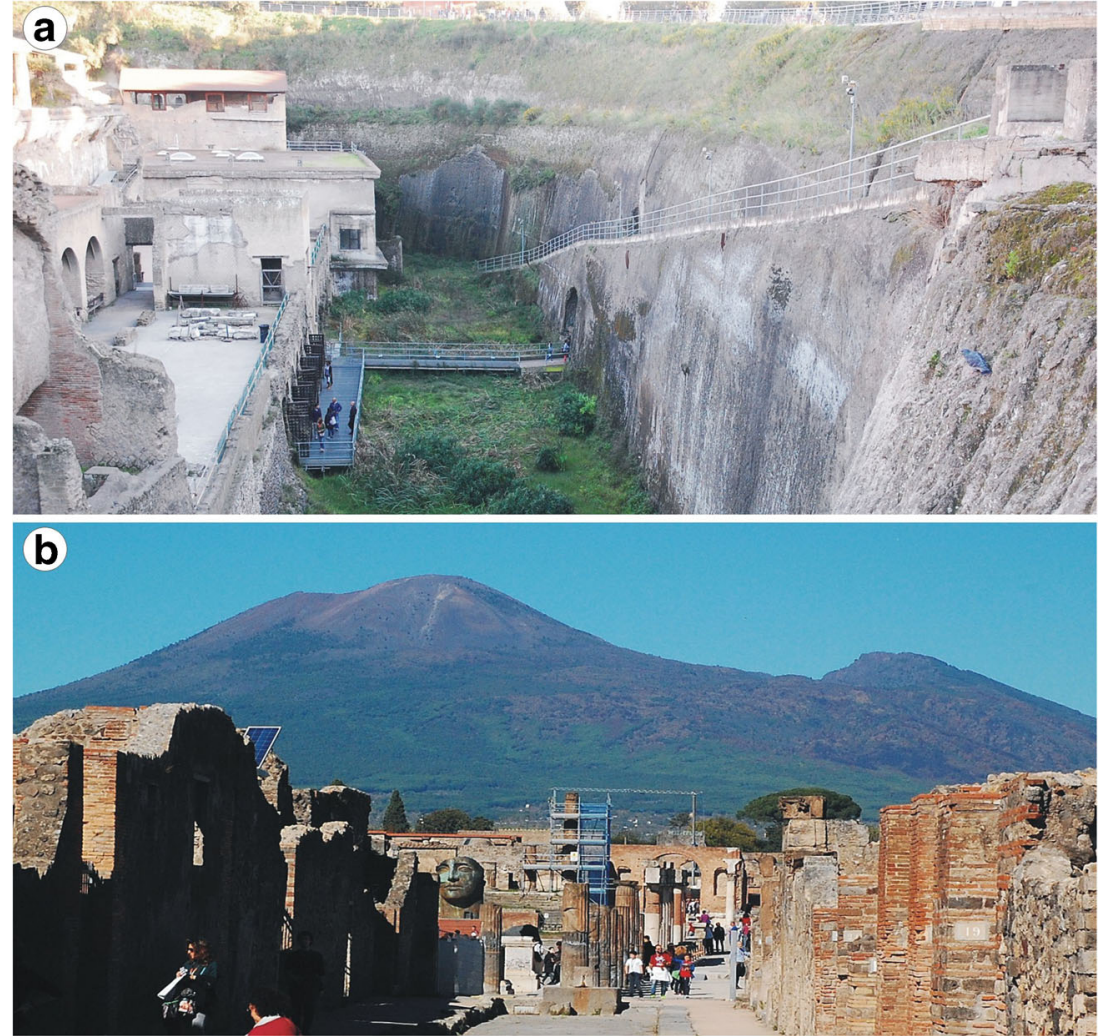

exposure of many towns and villages that occupy the lower slopes of Mt. Vesuvius and the surrounding plain. The focus is on archeological evidence of lifestyle in the Roman times and whereas the course of events in $79 \mathrm{AD}$ is reconstructed, particularly interesting in Pompeii using multimedia, the critical issue of developing ancient cities in high-risk areas is not really addressed.

\section{Santorini}

The Greek island of Santorini, famous for its colorful cliffs and picturesque villages, is part of the ancient volcanic island of Strongili, destroyed in the course of a powerful Minoan eruption believed to have occurred sometime between 1650 and 1600 BC (Lopes 2005; Gorokhovich 2013). As a consequence of the massive explosion the current caldera formed, c. $11 \mathrm{~km}$ in $\mathrm{N}-\mathrm{S}$ and $7.5 \mathrm{~km}$ in $\mathrm{W}-\mathrm{E}$ direction, partly submerged due to several breaches in the former volcano rim. The remnants of the stratovolcano include five islands. Among them, three form the open outer ring (Thira, Thirasia and Aspronisi) and two are located inside the caldera (Nea Kameni, Palea Kameni), the latter uninhabited.

The explosion annihilated the local Strongili society and wrought havoc among the Minoan civilization, centered on the island of Crete. Remains of settlements have been unearthed from beneath pyroclastic deposits on both Thera and Therasia. Some of the uncovered houses were three-story, had sewage amenities, and were richly decorated with frescoes. The most valuable archeological site is the partly excavated ancient town of Akrotiri, in the southern part of Thira (Doumas 2013, Gaki-Papanastassiou and Papanastassiou 2014). A section of the site was covered by a protective roof and opened to tourists, although some artifacts and frescoes have been transferred to the archeological museum in Athens.

Today, Santorini is among the most popular tourist destinations in the Aegean region, visited by approximately two million people annually. Volcanic tourism is part of the experience (Gaki-Papanastassiou and Papanastassiou 2014) and includes boat trips across the caldera and to the inner islands, where tourists can see evidence of ongoing volcanic activity such as lava fields, hot springs, and fumaroles. The high cliffs of Thira and Thirasia allow for comprehending the sheer size of the entire volcanic structure. The Kameni islands are protected as a geological park, and constant surveillance of volcanic activity is carried out by the Institute for the Study and Monitoring of Santorini Volcano (ISMOSAV). As part of its activity, the Institute prepared a range of publications for the general public (books, brochures, leaflets), but a geological museum is yet to be open (Gaki-Papanastassiou and Papanastassiou 2014). 


\section{Other Mediterranean Sites}

At a number of archeological sites in the Mediterranean region, one can see the evidence of building collapse and other damage due to earthquakes. Examples include fallen walls and other damaged structures at Hierapolis/Pamukkale in Turkey (Hancock et al. 2000), offset walls and fallen columns in numerous locations along the Dead Sea Transform fault system (Marco 2008), or pop-up structures in street pavements of the Roman town Baelo Claudia in southern Spain (Silva et al. 2005). One of the cities, whose prosperity was effectively terminated by an earthquake, is Kourion in the south-western part of Cyprus (Soren and James 1988), where archeological remains are among the most visited ancient sites of the island. Likewise, one of the best archeological sites in Sicily (Italy), Selinunte, bears evidence of extensive damage of temples by powerful prehistoric earthquakes (Guidoboni et al. 2002).

\section{Lisbon Earthquake and Tsunami}

The city of Lisbon was affected by a catastrophic earthquake on 1 November 1755, whose epicenter was located about $300 \mathrm{~km}$ to the SW, in the Atlantic Ocean (Paice 2008). The earthquake itself was followed by a series of tsunami waves some $40 \mathrm{~min}$ later, whereas frequent fires contributed to the city's destruction. It is estimated that several tens of thousands of people were killed and most of downtown Lisbon, including monumental buildings, libraries, and art collections, was destroyed beyond repair. The disaster was followed by a massive effort of rebuilding the city, involving a completely new urban layout. This was accomplished relatively quickly and the new district of Baixa remains a remarkable monument of post-disaster recovery rather than of the disaster itself. In fact, there is only one place in Lisbon, where remnants of the event were left to survive and these are the church ruins of the Convento do Carmo, a former medieval abbey, which is now housing an archeological museum. Otherwise, no locations within the city remind of the disaster, and the massive urban development along the River Tagus waterfront prompts whether the lesson of the 1755 earthquake has been learnt.

There are various locations along the coast of Portugal and south-west Spain where evidence of coastal change due to tsunamis can be observed. Among those places is Cape Trafalgar where huge imbricated aeolianite boulders on the shore platforms provide the testimony of the event (Whelan and Kelletat 2005; Gracia et al. 2006). In close proximity of Lisbon are tsunami-dislocated boulders west of Cascais (Scheffers and Kelletat 2005). However, this information is contained in specialist publications and no on-site interpretation about their origin is offered and hence, implications for the likelihood of another future event are not discussed.

\section{Recent Disaster Sites and Geotourism}

The distinctiveness of geotourism should manifest itself in the provision of interpretative facilities, which will enhance the experience of visitors and encourage them to learn and understand geology and geomorphology components of the natural environment (Hose 2012). This goal may be fulfilled by various means and in various places, but it is agreed that learning of this kind is most effectively accomplished at geosites, understood as specific locations of particular significance for geosciences and suitable to be managed as sites of interest and dissemination of knowledge (Reynard 2004). Although most geosites are developed to show elements of geoheritage, which is the record of the past, sites where natural geophysical disasters have occurred may be developed as geosites as well and used to teach about dynamics of the Earth's surface (Coratza and De Waele 2012). Particularly useful for this purpose are locations where some evidence of the disastrous event has survived, although engaging storytelling may to some extent replace the lack of such material evidence. There are two evident advantages of such an approach. First, visitors can still examine direct effects of an event rather than rely on archival photographs, animations, etc., which is a very different experience. Second, they can see the broader geographical (topographical) context of the disaster site, which helps both to explain the severity of an event and may provoke questions about rational land use. Table 2 lists means of interpretations used at disaster sites, which have been developed into objects of geotourist interest, along with selected examples.

The simplest form of keeping the memory of a disaster is to indicate the place where it occurred or the location affected. Perhaps, the oldest means of commemoration are flood marks, which show the level of inundation during various past events (Fig. 5). They are particularly common in western and central European countries and proved very helpful to carry out paleohydrological reconstructions (Herget 2012), although they are rarely accompanied by more detailed presentation of particular flood histories.

At various places, simple monuments have been erected, for example at the site of the deadliest railway disaster in the history of New Zealand, in Tangiwai (Fig. 6). Here, on 24 December 1953, a lahar triggered by a crater lake breakout at the summit of Mount Ruapehu swept away a railway bridge, just minutes before the train was to cross it. Next to the site stands a panel containing archival photographs from the rescue operations; however, it is short of explaining the physical aspects of the event.

In certain locations, some damaged structures have survived as living memories of a disaster, although not necessarily with the clear intention to become visitor attractions. Rather, for various reasons, demolishing such structures was considered unnecessary or perhaps too costly. However, they 
Table 2 Means of interpretation at past disaster sites (examples)

\begin{tabular}{lll}
\hline Means of interpretation & $\begin{array}{l}\text { Natural disaster } \\
\text { commemorated }\end{array}$ & Location \\
\hline $\begin{array}{l}\text { Commemorating plaque and } \\
\text { monument }\end{array}$ & Lahar & Tangiwai, New Zealand \\
& Flood & Obř́ důl, Czechia \\
Retained damaged & Earthquake & Cologne, Germany \\
infrastructure & & Lisbon, Portugal \\
& Volcanic eruption & Kobe, Japan \\
& Landslide & Wufeng, Taiwan \\
Interpretation board & San Juan Parangaricutiro (Paricutin \\
Educational trail & volcano), Mexico \\
& Volcanic eruption and & Vajont, Italy \\
Museums/visitor centers & Earthquake & Rapid City, S Dakota, USA \\
& & Te Wairoa, New Zealand \\
& Landslide & Wufeng, Taiwan \\
& Lobe, Japan \\
& Landslide and flood & Frank, Canada \\
\hline
\end{tabular}

have later gained significance as disaster memorials. Examples from ancient times have been mentioned in "Ancient Natural Disaster Sites as Objects of Tourist Interest," whereas among more recent ones is the church in San Juan Parangaricutiro, Mexico, which is half buried by a lava flow emerging from the Parícutin volcano in 1944 (Fig. 7). Although located in a rather less touristic part of Mexico, it frequently features in promotional materials and guidebooks.

In a special way, the huge 1970 debris flow, which occurred on the slopes of Mt. Huascaran (Peru) and annihilated the town of Yungay, killing more than 20,000 people, is commemorated. The entire area, where the town once stood, is now largely buried under several meters of mud and has been

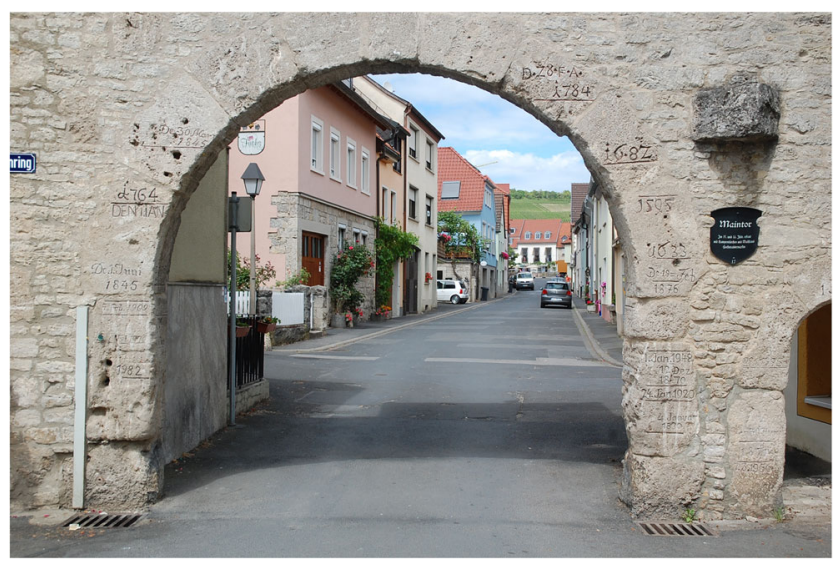

Fig. 5 Flood marks in the town of Eibelstadt, river Main, Germany (photo by P. Migoń) declared a sacred site, with the ruins of the local church as one of a few visible traces (Castaños and Lomnitz 2012). A twisted bus wreck recovered from the debris flow deposits demonstrates the power of the debris flow.

Interpretation panels provide more in-depth information about an event. For example, a panel was erected near the Vajont Dam in the Italian Alps (Fig. 3b), where a massive landslide into a reservoir caused the overflow of the dam and the instant release of 30 million cubic meters of water and a flood immediately downstream, resulting in approximately 2000 casualties in the town of Longarone and the vicinity (Semenza and Ghirotti 2000). The interpretation panel details the geological conditions of the site, not fully realized

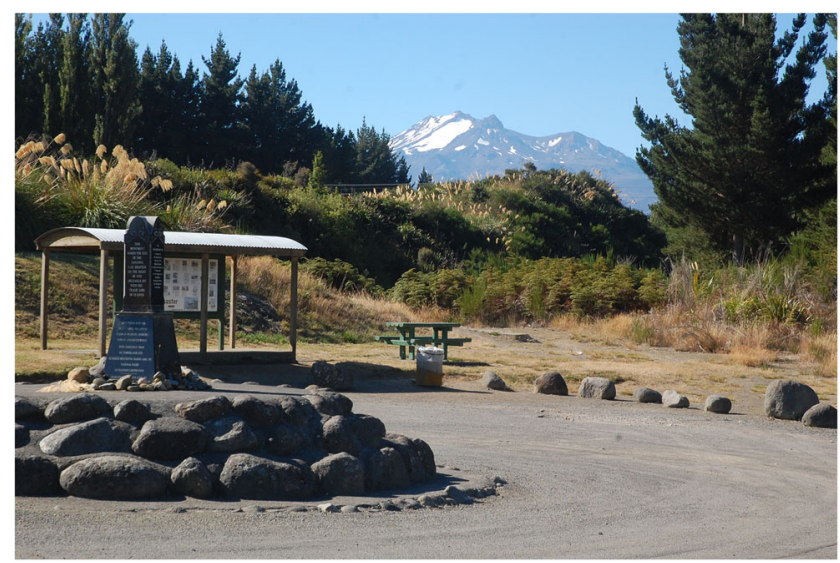

Fig. 6 Site of Tangiwai rail disaster due to lahar. The visibility of Mt. Ruapehu - the source area of lahar — is very advantageous from the point of view of geoscience and natural hazard education (photo by P. Migoń) 


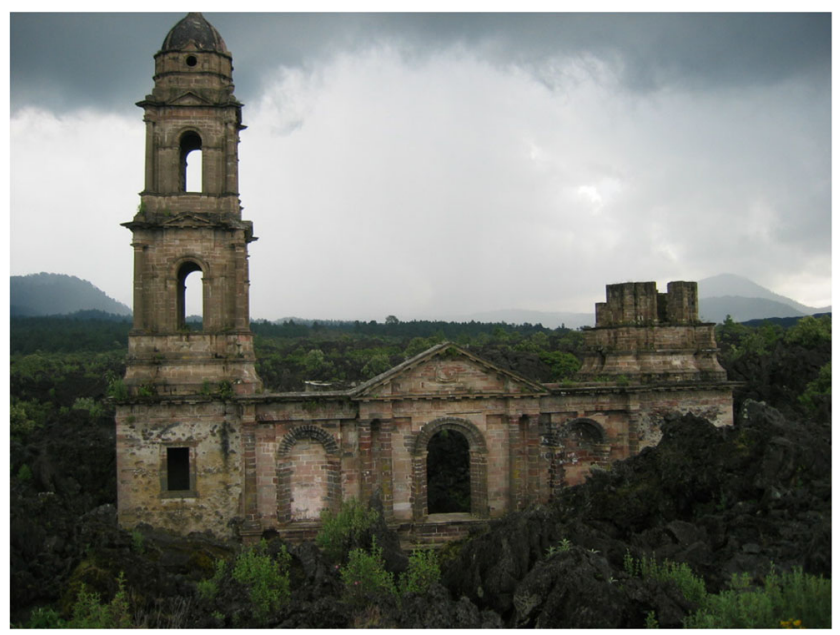

Fig. 7 Tower of ruined church in the former San Juan Parangaricutiro town, partly buried by a lava flow that emerged from the Parícutin volcano (Mexico) in 1944 (photo by P. Migoń)

as hazardous at the time of dam building, and the story of the landslide itself. Likewise, information panels inform about the 1964 tsunami that affected Crescent City in northern California and partially destroyed the nearshore part of the town and the much more recent, March 2011 tsunami.

Enhanced understanding of an event, including realization of its scale, can be achieved on an educational trail focused on a disaster and its legacy. One example is the trail that guides visitors around the former Maori village of Te Wairoa (New Zealand), buried by pyroclastic deposits ejected during the explosion of Tarawera volcano. Although no original buildings survived the event, several have been reconstructed, so that the depth of burial can be appreciated (Simmons 1991, Smith and Croy 2005).

Rapid City in south Dakota, USA provides an interesting example of a trail that commemorates an event whose tangible evidence has vanished (Herget, pers. comm.). The city was affected by a catastrophic flood on 9 June 1972, which destroyed nearly all buildings erected on the floodplain of Rapid Creek. Subsequently, realizing that similar events may reappear, the floodplain was not rebuilt but developed into a park. The trail across the park has 14 stops detailing both the nature of floods as natural phenomena as well specific stories from the 1972 disaster.

The most sophisticated means of educating about natural hazards and disasters are dedicated museums. The rather scarce on-site interpretation facilities near the Vajont Dam are complemented by a memorial museum in the town of Longarone, itself nearly annihilated during the disaster (Associazione Pro Loco Longarone 2018).

In Wufeng, central Taiwan, an earthquake museum was set up after the deadly 1999 (21 September) Chi-Chi tremor, which brought about substantial damage across much of the island and caused over 2400 casualties (Earthquake Engineering Research Institute 1999, Shin and Teng 2001).
This is a complex facility, developed on the former school grounds which happened to be located exactly across the fault trace (www.921 emt.edu.tw; accessed 2017-03-20). The museum includes partially collapsed school buildings under a protective roof (to be seen from outside), running ground vertically offset by $2 \mathrm{~m}$ along a fault scarp - a direct evidence of landform change due to seismic shock, an interpretative center focused on earthquakes and volcanoes, as well as discovery rooms to test stability of various building constructions (Fig. 8). Nearby, one can visit further evidence of the 1999 earthquake, deliberately retained. These are terrain steps signifying the location of the fault scarp, together with a tilted electricity pylon and a displaced railway line with twisted tracks. An important educational role of this museum has been confirmed in a recent visitors' survey by Ryan and Hsu (2011). Tang (2018) provides further East Asian examples of museums and interpretation centers dedicated to earthquakes, such as the 1976 Tangshan earthquake and 2008 Wenchuan earthquake, both in China, and notes that elements of damaged infrastructure are incorporated into the exhibition grounds. In Kobe, for example, part of a damaged pier was preserved in the Meriken Park, where the Port of Kobe Earthquake Memorial Park was set up after the 1995 earthquake (A. Latocha; pers. comm.).

In the state of Alberta in the Canadian Rocky Mountains, an interpretative center was built at the site of the Frank rock slide. The slide from the precipitous slope of Turtle Mountain occurred in 1903, killing at least 70 people in the mining town located at the foot of the mountain (Benko and Stead 1998). The interpretative center explains the slide history itself, offers a view towards the affected slope where both, the landslide scars and huge debris accumulations, are clearly visible and provide a range of interpretation programs for visitors of different ages, including one specifically dedicated to the recognition of the causes of the slide, named "Killer Mountain C.S.I." (Alberta Culture and Tourism 2018).

Another museum dedicated to natural hazards, this time with less tragic consequences, was established in the little town of Civita di Bagnoregio in central Italy (Margottini and Di Buduo 2017). The town was built on a narrow spur underlain by ignimbrite in the top part and stratified pyroclastic deposits, sands, and clays below, which is a geological setting promoting slope instability. The area has a long history of mass movements affecting the cliffed slopes and destroying buildings overlooking the cliffs, and slope instability is a persistent factor. The museum opened in 2012 in one of the town's historical buildings and tells the story about landslides, landslide hazard identification, and mitigation. A short walk outside leads visitors to the cliff edges, where the natural setting in which landslides occur can be observed.

Several further examples of similar educational facilities at former disaster sites are provided by Rucińska and Lechowicz (2014). 
Fig. 8 Earthquake museum in Wufeng, Taiwan. a Faultdisplaced running ground. $\mathbf{b}$ Collapsed school building. c Part of the exhibition. d Tilted electricity pylon nearby (all photos by P. Migoń)
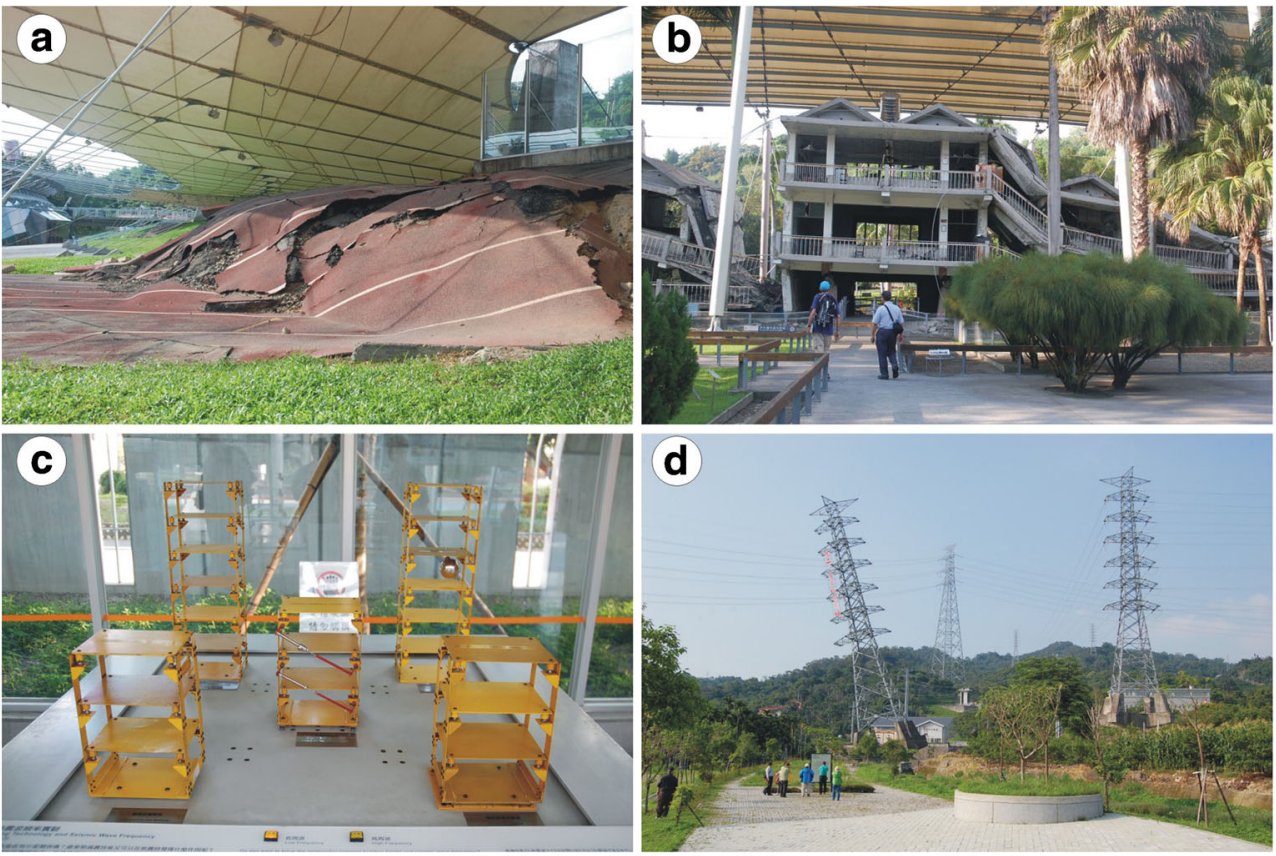

\section{Discussion and Recommendations}

\section{How Much Can Be Learned at Disaster Sites?}

Although the review in the preceding section provides only a sample of sites once affected by natural disasters, it is sufficient to illustrate the wide spectrum of approaches and diverse opportunities to learn. On the one side, there are locations which could serve as model sites to teach about disasters and their causes, but none or only rudimentary facilities exist on sites. An example of missing opportunity is the site of Tangiwai rail disaster in New Zealand (see "Recent Disaster Sites and Geotourism"). Although the Ruapehu volcano is visible from the site and hence, the link between the distant source of the lahar and the place of the tragedy is relatively obvious (Fig. 6), the information panel does not address this, even if despite the fact that lahars pose continuous threats around Ruapehu. On the other side, there are examples of comprehensive educational trails (Rapid City, USA) and sophisticated museum and/or interpretation centers linked to the disaster sites themselves (Wufeng, Taiwan; Frank, Canada). It is obviously the latter which will play a pivotal role in educating about hazards, vulnerability, and risk, whereas the former may be considered as lost opportunities. Single interpretation panels are better than nothing, but the knowledge provided may be insufficient.

A good case is provided by the Vajont landslide (Italy) where the location of the information panel near the dam, deep inside the valley, precludes appreciation of the geomorphic context of the slide. To do so, one would need to go on the opposite slope, to the village of Casso, where an observation deck was built on the roof of a building and which allows a complete view of the slide. However, neither the presence of such vantage site is signposted nor is the viewing deck itself equipped with any interpretation facilities (Fig. 3c). Developing locations allowing to see and appreciate the magnitude of the disaster would complement interpretation facilities available in the memorial museum in Longarone.

Different lessons can be taught at disaster sites. Each one, if interpreted, provides basic information about an event such as type, timing, extent, losses, and recovery. Going beyond simple information, the main message conveyed by the Wufeng (Taiwan) earthquake museum is that preparation is crucial, at the level of both building design and individual reactions to seismic shocks. This is consistent with the fact that if an earthquake strikes, land-use patterns matter little. However, it is very different on floodplains, where incorrect development may exacerbate losses as demonstrated by the Rapid City (USA) flood history. Main lessons should therefore be focused on land use planning adequate to the dynamics of the environment. Landslide and volcanic eruption sites are in turn optimal places to explore hazard and risk evaluation issues. It may seem trivial to emphasize that most effective teaching is carried out outdoors, where the geomorphic context of a disaster can be examined, but such sites are not too many.

\section{The Value of Disaster Sites as Geosites}

Geosites are locations particularly suited to enhance knowledge about the Earth, its geological history, and how it changes through the action of endogenous and surface processes. Disaster sites developed as geosites actually play a dual role. First, they help better understand natural forces, their power and 
abilities, magnitude-frequency relationships, and consequences for both, the natural environment and human societies. Thus, they stand out from the majority of geosites, which expose "frozen" geological records from ancient geological periods and inherited, apparently stable landforms. Second, they should assist in better comprehending the exposure to risk (Coratza and De Waele 2012). It is true that disaster-related losses could have been significantly smaller if exposure to risk would have been minimized by restrictions on land-use and settlement development. Adequately designed interpretation facilities, asking the right questions and providing more in-depth information, can play a tremendous educational role. The value of learning from past mistakes should offset doubts and moral dilemmas, if it is appropriate to develop a tourist destination based on a tragedy (see also Tang 2018).

\section{How to Develop Former Disaster Sites for Tourism?}

Given the variety of disastrous events and the diversity of circumstances before, during, and after these events, it is difficult to provide general recommendations how to develop geo-interpretative facilities. Site-specific solutions, adjusted to local natural and socioeconomic conditions, are inevitable. Nevertheless, the following thoughts can be offered:

- disasters, however tragic and devastating, may be regarded as opportunities to educate future generations and therefore, complete eradication of material evidence of an event is counterproductive as it also erases the event from the collective human memory.

- focus on disrupted lives (e.g., in the archetypal disaster site of Pompeii) honors victims but helps little to understand issues of vulnerability and risk.

- interpretation panels, apart from simple information role, have the potential to enhance knowledge about processes and should be designed accordingly. They are preferably erected at good vantage points, so that the site of an event can be seen in the wider context.

- thematic trails are even better solutions, as they show various aspects of a disaster, can link source/cause with effect and allow to comprehend the topographic context. - museums/interpretative centers are costly enterprises but their educational role is significant.

\section{Conclusions}

It is indisputable that natural disasters have long-lasting consequences, and it is understandable that rescue and rebuilding operations are undertaken with the aim to bring life back to normal as soon as possible. In this context, removal of tangible evidence of a disaster fulfills two goals: the affected land is reclaimed and psychological trauma may be more effectively overcome. However, in case of massive disasters, which involved considerable landform change over large areas (volcanic eruptions, large landslides), such removal may not be possible. Situations like these may be used as opportunities to enhance learning about the relationship between people, land use, natural processes, and high magnitude events by providing real-life examples. Successful stories of this kind are interpretative centers and museums in localities affected by past disasters such as the 1903 Frank slide in the Canadian Rocky Mountains or the Chi-Chi earthquake in Taiwan in 1999. It is argued that preserving some evidence of disasters, whether in the form of damaged buildings or natural features, may be beneficial for better understanding of causes and consequences of disasters for human society. It will also provide an additional educational dimension to geotourism, offering lessons about how the Earth's surface may rapidly change at any time.

Acknowledgements We are grateful to people who, in various ways, made it possible to visit some of the sites mentioned in this paper. These are Jiun Chuan-Lin, Michael Crozier, Juergen Herget, and Mauro Soldati. Juergen Herget is also thanked for providing information about the flood disaster trail in Rapid City. Agnieszka Latocha supplied information about the memorial grounds in Kobe. This paper is based on a presentation given by the lead author during a workshop on environmental hazards held at the University of Brno, Czechia, in late 2016. He is grateful to Karel Kirchner for the invitation to that meeting and the subsequent discussions. We acknowledge the work of reviewers on this paper, especially in respect to improving the quality of language.

Open Access This article is distributed under the terms of the Creative Commons Attribution 4.0 International License (http:// creativecommons.org/licenses/by/4.0/), which permits unrestricted use, distribution, and reproduction in any medium, provided you give appropriate credit to the original author(s) and the source, provide a link to the Creative Commons license, and indicate if changes were made.

\section{References}

Alberta Culture and Tourism (2018) Frank slide - Canada's deadliest rockslide. http://history.alberta.ca/frankslide/slidefacts/slidefacts. aspx. Accessed 10 March 2018

Alcantara-Ayala I (2010) Parícutin volcano: to the other side. In: Migoń P (ed) Geomorphological landscapes of the world. Springer, Dordrecht, pp 59-67

Alcantara-Ayala I, Goudie A (eds) (2010) Geomorphological hazards and disaster prevention. Cambridge Uni Press, Cambridge

Associazione Pro Loco Longarone (2018) Museo Longarone Vajont Attimi di storia-Longarone. Introduzione. http://www. prolocolongarone.it/vajont/il-museo-del-vajont/introduzione. Accessed 10 February 2018

Benko B, Stead D (1998) The Frank slide: a re-examination of the failure mechanism. Can Geotech J 35:299-311

Castaños H, Lomnitz C (2012) Earthquake disasters in Latin America. A holistic approach. Springer, Dordrecht

Chigira M, Wu X, Inokuchi T, Wang G (2010) Landslides induced by the 2008 Wenchuan earthquake, Sichuan, China. Geomorphology 118: 225-238 
Coratza P, De Waele J (2012) Geomorphosites and natural hazards: teaching the importance of geomorphology in society. Geoheritage 4: 195-203

Doumas C (2013) Managing the archaeological heritage: the case of Akrotiri, Thera (Santorini). Cons Manag Archaeol Sites 15:109-120

Earthquake Engineering Research Institute (1999) The Chi-Chi, Taiwan earthquake of September 21, 1999. https://www.eeri.org/lfe/pdf/ Taiwan ChiChi Insert Dec99.pdf. Accessed 28 May 2018

Erfurt-Cooper P (2011) Geotourism in volcanic and geothermal environments: playing with fire? Geoheritage 3:187-193

Foley M, Lennon JJ (1996) JFK and dark tourism - a fascination with assassination. Int J Heritage Stud 2(4):198-211

Gaki-Papanastassiou K, Papanastassiou D (2014) Volcano tourism in Greece: two case studies of volcanic islands. In: Erfurt-Cooper P (ed) Volcanic tourism destination. Springer, Heidelberg, pp 69-87

Galderisi A, Ceudech A (2013) Damage and the built environment. In: Bobrowsky P (ed) Encyclopedia of natural hazards. Springer, Dordrecht, pp 141-144

Gorokhovich Y (2013) Santorini, Eruption. In: Bobrowsky P (ed) Encyclopedia of natural hazards. Springer, Dordrecht, pp 884-895

Gracia FJ, Alonso C, Benavente J, Anfuso G, Del-Río L (2006) The different coastal records of the 1755 tsunami waves along the Atlantic Spanish coast. Z Geomorph NF Suppl 146:195-220

Guidoboni E, Muggia A, Marconi C, Boschi E (2002) A case study in archaeoseismology. The collapses of the Selinunte temples (southwestern Sicily): two earthquakes identified. Bull Seismol Soc Amer 92:2961-2982

Hancock PL, Chalmers RML, Altunel E, Cakir Z, Becher-Hancock A (2000) Creation and destruction of travertine monumental stone by earthquake faulting at Hierapolis, Turkey. Geol Soc, London, Spec Publ 171:1-14

Herget J (2012) Am Anfang war die Sintflut. Hochwasserkatastrophen in der Geschichte. WBG, Darmstadt

Hose TA (1995) Selling the story of Britain's stone. Env Interpret 10(2): $16-17$

Hose TA (2012) 3G's for modern geotourism. Geoheritage 4:7-24

Kelman I, Dodds R (2009) Developing a code of ethics for disaster tourism. Int J Mass Emerg Disast 27:272-296

Korstanje M, George B (2015) Dark tourism: Revisiting some philosophical issues. e-Rev Tour Res 12:127-136

Lindell MK (2013) Recovery and reconstruction after disasters. In: Bobrowsky P (ed) Encyclopedia of natural hazards. Springer, Dordrecht, pp 812-824

Lopes R (2005) The volcano adventure guide. Cambridge Uni Press, Cambridge

Marco S (2008) Recognition of earthquake-related damage in archaeological sites: examples from the Dead Sea fault zone. Tectonophysics 453:148-156

Margottini C, Di Buduo G (2017) The Geological and Landslides Museum of Civita di Bagnoregio (central Italy). Landslides 14: $435-445$

Miller DS (2008) Disaster tourism and disaster landscape attractions after Hurricane Katrina: an auto-ethnographic survey. Int J Cult Tour Hosp Res 2(2):115-131

Newsome D, Dowling RK (2005) The scope and nature of geotourism. In: Dowling RK, Newsome D (eds) Geotourism. ButterworthHeinemann, Oxford, pp 221-241

Paice E (2008) Wrath of God: the Great Lisbon earthquake of 1755. Quercus, London

Parise M, Gunn J (eds) (2007) Natural and anthropogenic hazards in karst areas: recognition, analysis and mitigation. Geol Soc, London, Spec Publ 279:1-3

Reynard E (2004) Geosite. In: Goudie AS (ed) Encyclopedia of geomorphology, vol 1. Routledge, London, p 440

Rucińska D (2016) Natural disaster tourism as type of dark tourism. Int Schol Sci Res Innov 10:1385-1389
Rucińska D, Lechowicz M (2014) Natural hazard and disaster tourism. Misc Geogr 18:17-25

Ryan C, Hsu SY (2011) Why do visitors go to museums? The case of 921 earthquake museum, Wufong, Taichung. Asia Pacific J Tourism Res 16:209-228

Saatcioglu M (2013) Structural damage caused by earthquakes. In: Bobrowsky P (ed) Encyclopedia of natural hazards. Springer, Dordrecht, pp 947-959

Scandone R, Giacomelli L (2014) Vesuvius, Pompei Herculaneum: a lesson in natural history. J Res Didact Geogr 2(3):33-41

Scheffers A, Kelletat D (2003) Sedimentologic and geomorphologic tsunami imprints worldwide - a review. Earth Sci Rev 63:83-92

Scheffers A, Kelletat D (2005) Tsunami relics on the coastal landscape west of Lisbon. Portugal Sci Tsunami Haz 23(1):3-16

Semenza E, Ghirotti M (2000) History of the 1963 Vaiont slide: the importance of geological factors. Bull Eng Geol Env 59:87-97

Seaton AV (1996) Guided by the dark: from thanatopsis to thanatourism. Int J Heritage Stud 2(4):234-244

Shin TC, Teng TL (2001) An overview of the 1999 Chi-Chi, Taiwan, earthquake. Bull Seismol Soc Amer 91:895-913

Shultz JM, Neria Y, Allen A, Espinel Z (2013) Psychological impacts of natural disasters. In: Bobrowsky P (ed) Encyclopedia of natural hazards. Springer, Dordrecht, pp 779-791

Sigurdsson H, Cashdollar S, Sparks RSJ (1982) The eruption of Vesuvius in A.D. 79: reconstruction from historical and volcanological evidence. Am J Archaeol 86:39-51

Silva PG, Borja F, Zazo C, Goy JL, Bardajı T, De Luque L, Lario J, Dabrio CJ (2005) Archaeoseismic record at the ancient Roman City of Baelo Claudia (Cádiz, south Spain). Tectonophysics 408: 129-146

Simmons A (1991) Te Wairoa, the buried village: the summary of recent research and excavations. Austr Hist Archaeology 9:56-62

Smith N, Croy WG (2005) Presentation of dark tourism: Te Wairoa, the buried village. In: Ryan C, Page SJ, Aicken M (eds) Taking tourism to the limits: issues, concepts and managerial perspectives. Elsevier, Oxford, pp 199-213

Soren D, James J (1988) Kourion. The search for a lost Roman city Anchor Press, Berkeley

Stone PR, Hartman R, Seaton T, Sharpley R, White L (2018) The Palgrave handbook of dark tourism studies. Palgrave Macmillan, London

Szczuciński W (2012) The post-depositional changes of the onshore 2004 tsunami deposits on the Andaman Sea coast of Thailand. Nat Haz 60:115-133

Tanaś S (2013) Tourism 'death space' and thanatourism in Poland. Curr Iss Tour Res 3(1):22-27

Tang C, Zhu J, Qi X, Ding J (2011) Landslides induced by the Wenchuan earthquake and the subsequent strong rainfall event: a case study in the Beichuan area of China. Eng Geol 122:22-33

Tang Y (2018) Dark tourism to seismic memorial sites. In: Stone PR, Hartman R, Seaton T, Sharpley R, White L (eds) The Palgrave handbook of dark tourism studies. Palgrave Macmillan, London, pp 423-441

Timothy D, Boyd S (2003) Heritage tourism. Prentice Hall, Harlow

Wallace A (2012) Presenting Pompeii: steps towards reconciling conservation and tourism at an ancient site. Papers from Institute of Archeology 22:115-136

Wallace RE (1977) Profiles and ages of young fault scarps, north-central Nevada. Geol Soc Amer Bull 88:1267-1281

Waltham T, Bell F, Culshaw M (eds) (2005) Sinkholes and subsidence: karst and cavernous rocks in engineering and construction. Springer

Whelan F, Kelletat D (2005) Boulder deposits on the southern Spanish Atlantic Coast: possible evidence for the 1755 AD Lisbon tsunami? Sci Tsunami Haz 23(3):25-38

Wohl EE (2000) Geomorphic effects of floods. In: Wohl EE (ed) Inland flood hazards: human, riparian, and aquatic communities. Cambridge Uni Press, Cambridge, pp 167-193 